\title{
Enantioselective Low-Temperature 1,4-Addition of Arylboronic Acids
}

\section{Key words}

rhodium

asymmetric 1,4-addition<smiles>O=C1C=CCCC1</smiles>
$\underset{\mathrm{PhMe}-\mathrm{H}_{2} \mathrm{O}(1: 1),-40^{\circ} \mathrm{C}}{\stackrel{(R)-\mathrm{MeO}-\mathrm{F}_{12}-\mathrm{BIPHEP}(0.5 \mathrm{~mol} \%)}{\longrightarrow}}$<smiles>[R]N1C(=O)C=CC1=O</smiles>

$\mathrm{R}=\mathrm{Alk}, \mathrm{Ar}, \mathrm{H}$

Selected examples:<smiles>CN1C(=O)CC(c2ccccc2)C1=O</smiles>

$95 \%$ yield, $92 \%$ ee $\left(-40^{\circ} \mathrm{C}\right)$<smiles>O=C1C[C@H](c2ccccc2)C(=O)N1Cc1ccccc1</smiles>

$95 \%$ yield, $95 \%$ ee $\left(-10^{\circ} \mathrm{C}\right)$<smiles>CN1C(=O)CC(c2ccccc2F)C1=O</smiles>

$99 \%$ yield, $91 \%$ ee $\left(0^{\circ} \mathrm{C}\right)$<smiles>O=C1CC(c2ccccc2)C(=O)N1C1CCCCC1</smiles>

96\% yield, $99 \%$ ee $\left(-10^{\circ} \mathrm{C}\right)$ (R)-MeO-F ${ }_{12}$-BIPHEP (0.5 mol\%)
$[\mathrm{RhOH}(\mathrm{cod})]_{2}(0.25 \mathrm{~mol} \%)$

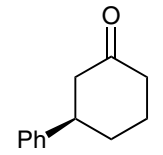

$87 \%$ yield $99.7 \%$ ee

$[\mathrm{RhOH}(\mathrm{cod})]_{2}(0.25 \mathrm{~mol} \%)$

$\mathrm{Et}_{2} \mathrm{O}-\mathrm{H}_{2} \mathrm{O}(7: 1),<0{ }^{\circ} \mathrm{C}$<smiles>[R]N1C(=O)C[C@@H]([Al])C1=O</smiles>

92-99\% yield $87-99 \%$ ee

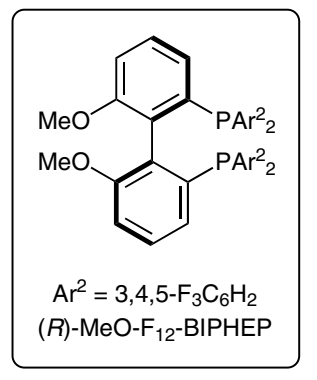

arylboronic acids

$\alpha, \beta$-unsaturated carbonyls

low-temperature addition

Significance: Although various chiral rhodium catalysts have been developed, the rhodiumcatalyzed asymmetric conjugate addition of arylboronic acids to $\alpha, \beta$-unsaturated carbonyl compounds below $0{ }^{\circ} \mathrm{C}$ has not been achieved. This paper describes the rhodium-catalyzed enantioselective 1,4-addition of arylboronic acids at low temperature. The use of the highly electron-poor $(R)-\mathrm{MeO}_{12}-\mathrm{F}_{12}$-BIPHEP ligand can retain the activity of the rhodium catalyst, which can serve to improve enantioselectivities.<smiles>COc1ccccc1C1CC(=O)N(C)C1=O</smiles>

$97 \%$ yield, $95 \%$ ee $\left(0^{\circ} \mathrm{C}\right)$<smiles>O=C1CC(c2ccccc2)C(=O)N1c1ccccc1</smiles>

$95 \%$ yield, $99 \%$ ee $\left(-10^{\circ} \mathrm{C}\right)$<smiles>CN1C(=O)CC(c2cccc(Cl)c2)C1=O</smiles>

$98 \%$ yield, $92 \%$ ee $\left(0^{\circ} \mathrm{C}\right)$<smiles>O=C1CC(c2ccccc2)C(=O)N1</smiles>

$94 \%$ yield, $87 \%$ ee $\left(-50^{\circ} \mathrm{C}\right)$

SYNFACTS Contributors: Hisashi Yamamoto, Yusuke Ano Dol: 10.1055/s-0033-1340439; Reg-No.: H16013SF

Comment: A variety of $\mathrm{N}$-substituted maleimides are applicable to this method, affording the corresponding chiral succinimides in excellent yields and enantioselectivities. Notably, the enantioselective 1,4-addition to $\mathrm{N}$-H-maleimide, which has been reported as an inactive substrate for rhodium-catalyzed asymmetric 1,4-addition, is also successful. When the reaction is performed at $-50{ }^{\circ} \mathrm{C}$, the enantioselectivity is improved to up to $87 \%$ ee. 